\title{
Sikap Siswa Terhadap Pembelajaran Seni Tari Di Masa Pandemi Covid-19
}

\author{
Yuli Tri Astuti ${ }^{1, *}$, Wahyu Lestari ${ }^{1}$, Agus Cahyono ${ }^{1}$ \\ ${ }^{1}$ Fakultas Pendidikan Seni; Universitas Negeri Semarang; Jl.Kelud Utara III Semarang \\ 50237, telp/fax (024) 8449017/8449969; e-mail: yulie tri91@students.unnes.ac.id; \\ wahyupyarlestari@mail.unnes.ac.id; aguscahyono@mail.unnes.ac.id \\ * Korespondensi: e-mail: yulie_tri91@students.unnes.ac.id \\ Submitted: 25/12/2020; Revised: 05/01/2021; Accepted: 11/01/2021; Published: 15/01/2021
}

\begin{abstract}
Attitude is something that is shown in humans. By showing a reaction from that person. Attitudes that can be seen directly indicate the existence of a response given. Indirectly, emotional traits or attitudes that can capture social stimuli. During the Covid-19 pandemic, learning dance can be done online by searching for sources on YouTube by viewing various kinds of dance videos. Learning to do various kinds of learning media, one of which is a program called happy at home broadcast on social media Youtube with my cultural account as a real form of government advancing culture. Also as an active role in helping arts and cultural workers affected by the Covid-19 pandemic. This study aims to determine students' attitudes in studying cultural arts during the Covid-19 pandemic. Learning is an important thing that is done in an educational process. Therefore we need the right learning strategy. Learning strategies that can be done are through online activities. Online activities can also help improve aspects of child development because one of the goals of learning dance strategies during a pandemic is to improve aspects of character development. The purpose of this article is to find out how to learn to dance during a pandemic. The method used in this article is to use the idea of thinking or this writing is a non-research scientific work, so it is an organized and systematic thought.
\end{abstract}

Keywords: Attitude, Learning, The Covid-19 pandemic

\begin{abstract}
Abstrak
Sikap merupakan sesuatu yang ditunjukan yang ada didalam diri manusia. Dengan menunjukan suatu reaksi dari seseorang tersebut. Sikap yang bisa dilihat secara langsung menunjukkan keberadaan suatu respon yang diberikan. Secara tidak langsung sifat atau sikap emosional yang bisa menangkap stimulus sosial. Selama masa pandemi Covid-19pembelajaran seni tari dapat dilakukan secara daring dengan mencari sumber-sumber yang ada di youtube dengan melihat berbagai macam video tari. Pembelajaran melakukan berbagai macam media pembelajaran, salah satunya program yang diberi nama bahagia dirumah itu disiarkan di media sosial Youtube dengan akun budaya saya sebagai wujud nyata pemerintah memajukan kebudayaan. Juga sebagai bentuk peran aktif membantu pekerja seni dan budaya yang terdampak pandemi Covid-19. Penelitian ini bertujuan untuk mengetahui sikap siswa dalam mempelajari seni budaya pada saat pandemi Covid-19. Pembelajaran merupakan hal penting yang dilakukan dalam suatu proses pendidikan. Oleh karena itu diperlukan strategi pembelajaran yang tepat. Strategi pembelajaran yang dapat dilakukan adalah melalui aktivitas online. Kegiatan online juga dapat membantu meningkatkan aspek perkembangan anak karena salah satu tujuan pembelajaran strategi menari pada masa pandemi adalah untuk meningkatkan aspek perkembangan karakter. Tujuan artikel ini adalah untuk mengetahui cara belajar menari selama pandemi. Metode yang digunakan dalam artikel ini adalah dengan menggunakan gagasan berfikir atau tulisan ini merupakan karya ilmiah yang non penelitian, sehingga merupakan pemikiran yang terorganisir dan sistematis.
\end{abstract}


Kata kunci: Sikap, Pembelajaran, Pandemi Covid-19

\section{Pendahuluan}

Sikap merupakan sesuatu yang ditunjukan yang ada didalam diri manusia. Dengan menunjukan suatu reaksi dari seseorang tersebut. Sikap yang bisa dilihat secara langsung menunjukkan keberadaan suatu respon yang diberikan. Secara tidak langsung sifat atau sikap emosional yang bisa menangkap stimulus sosial. Untuk dapat bersikap menentukan jenis tabiat tingkah laku antara hubungannya dengan apa yang dilakukannya oleh orang tersebut. Sikap yang ditunjukan tidak semuanya memiliki faktor internal.

Pembelajaran merupakan proses pendidikan yang dilakukan duntuk mendapatkan sesuatu yang diharapkan dalam mendidik, mengajar dan membimbing untuk menghasilkan sesuai yang lebih baik. Oleh karena itu dibutuhkan strategi pembelajaran yang tepat. Adapun strategi pembelajaran yang dapat dilakukan adalah melalui kegiatan daring. Kegiatan daring juga dapat membantu meningkatkan aspek perkembangan anak karena salah satu tujuan strategi pembelajaran seni tari dimasa pandemi adalah meningkatkan aspek perkembangan karakter. Tujuan yang hendak dicapai dalam artikel ini adalah mengetahui cara belajar seni tari dimasa pandemi.

Metode untuk dapat bisa menyusun kerangka berfikir yaitu dengan menggunakan metode dalam artikel yang terdahulu. Seperti hal nya dapat melihat pada asrtikel karya ilmiah yang termasuk non penelitian, sehingga didalam artikel yang ada dapat melihat gagasangagasan yang terorganisir san sistematik. Hasil dari gagasan berfikir ini adalah strategi pembelajaran seni tari dapat membantu dalam menumbuhkan minat belajar pada anak. Pada masa pandemi Covid-19, strategi pembelajararan yang cocok di terapkan di adalah dengan menggunakan metode daring, karena dengan metode daring dapat menghilangkan kejenuhan belajar pada anak dan anak lebih santai dan kapapun bisa mengikuti pembelajaran walaupun anak cenderung lebih enjoy santai mengikutinya.

Kata "Pembelajaran" adalah terjemahan dari "intruc-tion" yang banyak dipakai dalam dunia pendidikan di Amerika Serikat. Kata pembelajaran banyak dipengaruhi oleh aliran psikologi kognitif-wholistik yang memiliki arti menempatkan peserta didik sebagai sumber dari suatu kegiatan. Istilah pembelajaran dapat dipengaruhi oleh perkembangan teknologi yang diasumsikan dapat mempermudah siswa mempelajari segala sesuatu lewat berbagai macama media, seperti bahan-bahan cetak, program televisi, gambar, audia dan lain sebagainya sehingga semua itu mendorong terjadi perubahan peranan guru dalam mengolah proses belajar mengajar, dari guru sebagai sumber belajar menjadi guru sebagai fasilitator dalam belajar mengajar (Arifin, 2020).

Kondisi lingkungan yang dihadap saat ini dalam pembelajaran online harus tetap dilaksanakan. Seorang pendidik akan dituntut untuk dapat melakukan dan menjalankan peran secara professional dan mampu mengadapi semua tantangan dengan bergantinya jaman. Tugas seorang pendidik menjadi sangat komplek untuk merancang ulang pembelajaran yang 
dibuat nyaman dan tentunya mampu dipahami oleh semua peserta didik. Kesulitan yang dihadapi guru dalam pembelajaran seni tari pada masa pandemi Covid-19 adalah mengajarkan praktek dalam pembelajaran seni tari. Seorang guru melakukan sesuatu hal yang berbeda dalam memberikan materi pelajaran kepada peserta didik. Guru yang sudah familiar dengan aplikasi digital tidak perlu khawatir menemukan kesulitan. Ide yang dilakukan guru merupakan sebuah momentum untuk mengasah kemampuannya dalam membuat pembelajaran e-learning. Pembelajaran yang dapat dilakukan oleh siswa sehingga siswa merasa senang dan nyaman untuk mengikuti pembelajaran.

Selama masa pandemi Covid-19 pembelajaran seni tari dapat dilakukan secara daring dengan mencari sumber-sumber yang ada di Youtube dengan melihat berbagai macam video tari. Pembelajaran melakukan berbagai macam media pembelajaran, salah satunya program yang diberi nama bahagia dirumah itu disiarkan di media sosial Youtube dengan akun budaya saya sebagai wujud nyata pemerintah memajukan kebudayaan. Juga sebagai bentuk peran aktif membantu pekerja seni dan budaya yang terdampak pandemi Covid- 19 .

Dalam perkembangan ke depan, pemerintah akan menyediakan platform yang besar untuk menjangkau masyarakat yang lebih luas, misalnya melalui siaran televisi, dan menggandeng lebih banyak komunitas kreatif dan mengembangkan perilaku malas belajar yang dilakukan peserta didik termasuk salah satu dampak peserta didik yang suka bermain ponsel disepanjang harinya. Peserta didik yang malas belajar dikarenakan terlalu sibuk bermain ponsel, kids zaman now kebanyakan malas belajar dirumah karena tidak leluasa ketika dirumah diawasi oleh orang tuanya. Kebanyakan peserta didik tidak mau untuk mengerjakan tugas yang diberikan oleh guru bahkan ada yang berani untuk membolos saat lupa membuat tugas. Peserta didik pun dengan mudah mencontoh hasil pekerjaan temannya atau menyalin dari dunia maya melalui pencarian di Google.

Generasi kids zaman now banyak yang malas melakukan membaca dan menulis dengan alasan bikin ngantuk dan lain-lain. Perkembangan pada zaman now memiliki segala sesuatu yang semuanya canggih, bukanya semakin gemar membaca, kegiatan ini justru susah mereka lakukan. Membaca dapat membuat semua ilmu yang sudah dipelajari dari buku akan bermanfaat untuk otak. Kebiasaan anak dalam membaca akan memberi pengaruh yang positif bagi dirinya, yakni dapat meningkatkan daya ingat yang bagus. Sayangnya, generasi kids zaman now kebanyakan tidak menyadari hal ini. Hal yang sama terjadi pada kegiatan menulis. Pada saat ini, pesrta didik cenderung tidak suka menulis. Peserta didik yang memiliki kebiasaan suka menulis maka otaknya akan terlatih dan kreativitas dalam pemikirannya akan tersalurkan.

Intensitas bermain yang berlebihan salah satu perbedaan generasi muda generasi $Y$ dan $Z$ ialah intensitas bermain mereka, jika generasi $Y$ akan mengadakan kumpul bersama temannya maka mereka lebih memilih pada siang hari. Generasi $Z$ menunjukan bahwa apa yang terjadi dalam hal ini sudah lebih parah dari itu, yakni "sering berangkat malam pulang pagi hari”. Generasi Z, lahir dari tahun 1995 hingga 2010, merupakan generasi transisi 
Generasi $Y$ dengan teknologi yang lebih berkembang (Tannehill, Serapiglia, Guiler, \& Sharp, 2018). Generasi $Z$ mencapai usia dewasa pada dekade kedua abad ke-21. Begitu juga dengan mereka yang masuk Generasi $Z$ menerima kesenian tradisional dalam bentuk yang sudah ada secara turun temurun, atau apakah mereka bereaksi dengan kreativitas? Ini perlu dikaji dalam konteks pembelajaran seni. Kebiasaan buruk seperti ini memberikan dampak negative bagi peserta didik lainnya. Galau merupakan sesuatu yang sering dialami peserta didik yang sering merasakan kegelisahan dalam hal apapun. Bisa jadi ada hubungannya dengan usia mereka, yakni remaja menuju 44 Manajemen Pembelajaran Pendidikan Jarak Jauh untuk Millenial Manajemen Pembelajaran Pendidikan Jarak Jauh untuk Millenial 4546 dewasa. Pada saat ini yang bisa ditandai ciri khas mereka yang masih suka berperilaku labil dan berubah-ubah pikirannya. Galau nyaris menjadi makanan sehari-hari kids zaman now. Biasanya masalah paling utama adalah asmara atau cinta (cinta monyet). Pada dasarnya, galau itu boleh saja tetapi, banyak remaja-remaja jaman sekarang terlampau berlebihan dalam menghadapi kegalauan. Ada yang tidak mau keluar kamar, menolak bertemu teman, atau melamun sepanjang hari. Sebagai orang tua harus bisa memberikan pencerahan pada anaknya. Peserta didik juga patut diingatkan bahwa intensitas ibadah yang kurang menjadi penyebab mereka sering merasakan galau secara berlebihan baga budaya.

\section{Metode Penelitian}

Metode peleniltian yang digunakan dalam penelitian sikap siswa terhadap pembelajaran seni tari di masa pandemi covid-19 adalah menggunakan metode pendekatan kualitatif (qualitatif approach). Pemilihan metode kualitatif didasarkan atas perumusan masalah yang akan dicari jawabannya dari penelitian yaitu berupa pertanyaan "bagaimana" (how) dan "mengapa" (why) (Salim et al., 2006). Dalam pendekatan ini digunakan data deskriptif berupa kata-kata tertulis atau lisan dari orang-orang dan perilaku yang diamati, baik dalam bahasanya, peristilahannya dan kawasannya (Selfiyani, 2011).

\section{Hasil dan Pembahasan}

Dalam pembahasan bab ini, kita dapat mengetahui lebih jauh tentang Sikap Siswa Terhadap Pembelajaran Seni Budaya di Masa Pandemi. Ada fenomena seorang pendidik menuntut peserta didiknya untuk harus sempurna dalam mengikuti Pendidikan Jarak Jauh (PJJ) daring, sementara banyak sekali kendala teknis/psikis yang dialami oleh peserta didik dan wali peserta didik di masa pandemi Covid-19. Mengatasi hal itu harus ada evaluasi yang diadakan dari pihak sekolah dan melakukan home visit ke rumah peserta didik untuk bisa menggali persoalan yang ada dan dicari solusi yang tepat. Kondisi yang darurat seperti ini sekolah dapat menggunakan kurikulum darurat, ketercapaian kurikulum tidak diprioritaskan, pendidik juga tidak boleh memaksa peserta didik untuk menggunakan cara-cara tertentu. Pola PJJ harus disesuaikan dengan situasi dan kondisi peserta didik, misalnya di daerah yang miskin sinyal tidak boleh dipaksakan online dan seterusnya (Arifin, 2020) 
Home visit yang sudah dilakukan secara itensif dan terencana akan mengalami kesulitan untuk melakukan home visit, karena dengan meningkatnya kasus Covid-19 maka home visit diberhetikan dengan pertimbangan untuk pencegahan/penularan Covid-19. Persoalan yang dihadapi peserta didik/wali peserta didik maka digunakanlah komunikasi online atau komunikasi-komunikasi lainya yang lebih aman. Media masa yang diharapkan bisa membantu dan menjembatani berbagai macam kendala PJJ yang dialami oleh guru, siswa dan orang tuanya.

Pembelajaran online akan kurang bermakna apabila tanpa sinergitas strategi dan metode pembelajaran yang lebih tepat. Salah satu yang dilakukan dalam penerapan yang dapat memadukan pembelajaran online adalah pembelajaran berbasis proyek. Komponen yang paling utama dalam pembelajaran berbasis proyek adalah mengajukan pertanyaan atau masalah yang disajikan untuk menyusun dan memulai aktivitas yang menekankan kepada sejumlah proyek sampai didapatkannya hasil akhir berupa produk sebagai rangkaian aktivitas komunikasi individu atau berbagai hasil tugas yang menjawab pertanyaan (Susilo \& Sofiarini, 2020).

Kepada dunia pendidikan, Covid-19 telah mengubah banyak hal. Pendidikan yang menjadi dampak dalam masa pandemi Covid-19 sehingga ada sekitar 404 ribu sekolah jenjang sekolah dasar hingga menengah harus terpaksa ditutup. Ada 51 juta peserta didik baik PAUD, SD, SMP, hingga SMA, SMK, dan SLB yang keluar dari ruang kelas tidak menggunakan kelas dalam pembelajaran karen pada saat ini pembelajaran dilakukan secara daring. Semua sekolahan melakukan hal baru dengan pembelajaran secara online tanpa melakukan persiapan yang matang, sehingga sekolah-sekolah formal dengan dipaksa menggunakan aplikasi media pembelajaran jarak jauh untuk menggantikan pembelajaran tatap muka di kelas. Guru mendadak dipaksa untuk melakukan sesuatu yang berbeda dalam pemberian pelajaran kepada siswa. Guru-guru yang familiar dengan aplikasi digital tentu tidak terlalu menemukan atau mengalami kesulitan yang berarti. Bagi guru hal seperti ini sebagai momentum untuk mengasah kemampuannya agar dapat membuat pembelajaran secara e-learning. Pembelajaran masih bisa dilakukan oleh peserta didik agar merasa senang dan nyaman dalam belajar (Moore, Dickson-Deane, \& Galyen, 2011).

Kreativitas yang ada dalam pembelajaran merupakan kreativitas yang dipandang sebagai faktor pendukung dalam istilah yang banyak digunakan oleh guru, baik di dalam lingkungan sekolah maupun di luar sekolah. Pada umumnya orang menghubungkan kreativitas dengan produk-produk kreasi. Produk-produk kreasi itu merupakan sesuatu yang dianggap penting untuk menilai kreativitas. Jumlah guru didaerah tertentu yang amat terbatas, maka hal ini akan mempersulit untuk kelancaran pembelajaran yang akan dilakukan saat ini apa lagi jika dibandingkan dengan jumlah siswa yang sangat banyak. Guru akan mengalami canggung dan ragu-ragu memanfaatkan model pembelajaran secara daring. Guru memilih untuk mengeluarkan jurus pamungkas, dengan memberi tugas kepada peserta didiknya. Ada pihak yang turut membantu, membuat tayangan TV misalnya, namun sayang pembelajaran yang 
disuguhkan masih ala kadarnya, yang penting ada kegiatan belajar online (Setiawan, Puspaningrum, \& Umam, 2019).

Kegiatan pembelajaran di tengah pandemi Covid-19 yang dilakukan oleh Sekolah terkesan hanya dibuat dalam jangka pendek dan bersifat sementara, sambil menunggu perkembangan. Mereka Wait and See, sambil berharap pandemi segera berakhir dan pembelajaran bisa kembali dilakukan seperti biasa. Manusia bisa hidup tanpa kesenian, namun manusia tidak dapat dipisahkan dari kesenian. Berkesenian khususnya seni tari dalam media pembelajaran dapat dilakukan dengan cara daring, karena seni tari merupakan yang penggerak dalam lingkungan kebudayaan.

\subsection{Inovasi Pembelajaran Daring}

Pada masa pademi Covid-19, semua sekolah akan melakukan transformasi total dalam sistem pendidikan semua itu tentu saja tidak akan mudah, sehingga kita membutuhkan adanya 'Survival Innovation'. Gagasan utama yang ada dalam Survival Innovation gagasan yang dapat dilakukan yaitu: gagasan Digital Innovation, atau integrasi teknologi informasi dalam pendidikan pada tingkat depan dari pendidikan yaitu tingkat sekolah. Inovasi yang dihadapi untuk pembelajaran daring dapat dilakukan secara cepat, karena untuk mewujudkan suatu harapan secara terstuktur dan sistematis serta harus ada jaminan inovasi digital berupa pendidikan online menjadi komponen integral model pendidikan hibrid di sekolah (Prajana et al., 2018).

Siswa dapat diberikan akses teknologi ke berbagai sumber belajar dan bahkan dibimbing untuk belajar keterampilan teknis melalui media yang digunakan yaitu menggunakan alat-alat canggih seperti komputer, laptop, tablet dan ponsel yang bisa langsung terhubung dengan internet. Siswa yang memiliki akses ke teknologi dapat memanfaatkan berbagai macam akses yang sesuai dengan kebutuhan siswa. Semua yang dapat dilakukan dalam pembelajaran online dapat dibuktikan bahwa belajar online bisa lebih efektif dalam berbagai cara. Ada yang melakukan penelitian yang menunjukkan bahwa ratarata, siswa mempertahankan $25-60 \%$ lebih banyak mendapatkan materi yang dapat diserap di dalam otaknya ketika belajar online dibandingkan dengan hanya $8-10 \%$ yang dilaakukan di ruang kelas. Semua itu terjadi karena sebagian besar kemampuan siswa dapat belajar lebih cepat secara online. E-learning membutuhkan kurang lebih 40-60\% lebih sedikit waktu untuk dapat belajar dari pada berada di lingkungan kelas yang tradisional, karena siswa dapat belajar dengan cara mereka sendiri, kembali dan membaca kembali, melewatkan, atau mempercepat melalui konsep yang mereka pilih sendiri (Moore et al., 2011).

Efektivitas yang dilakukan dalam pembelajaran online dapat bervariasi diantaranya dari pengelomokan tugas belajar. Ada beberapa pendapat bahwa secara umum anak-anak yang lebih muda memerlukan lingkungan yang terstruktur, karena anak-anak tersebut lebih mudah terganggu. Pembelajaran yang diharpkan agar mendapatkan sesuatu yang manfaat dan penuh arti dari pembelajaran online, perlu ada upaya bersama untuk menyediakan struktur ini. Dengan mereplikasi kelas fisik melalui kemampuan video, menggunakan berbagai 
alat kolaborasi dan metode keterlibatan menggugah inklusi, personalisasi dan intelijen dari siswa (Alaby, 2020)

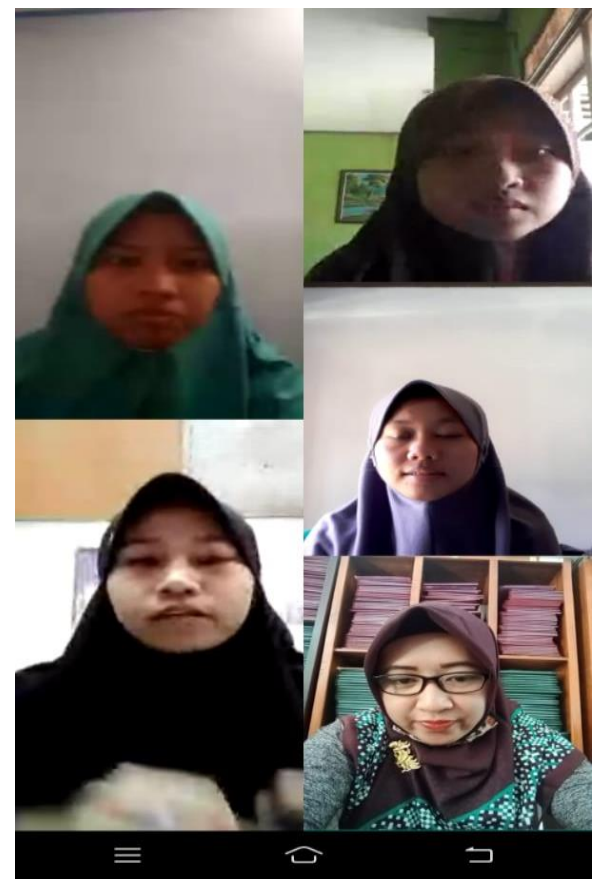

Sumber: Hasil Penelitian (2020)

Gambar 1. Kegiatan Pembelajaran Online

Pada Gambar 1 dijelaskan tentang pembelajaran online dengan menggunakan aplikasi whatsaap dengan video call guru menjelaskan berbagaimacam arahan kiat-kiat belajar dalam pembelajaran daring.

Untuk mengatasi keadaan yang seperti itu dihendaki bagi pimpinan sekolah untuk mempersiapkan tenaga pengajarnya menjadi fasilitator pengembangan kompetensi siswa dan sekaligus sebagai pencipta konten pendidikan digital yang handal dalam waktu cepat. Inovasi di era digital tidak melulu dimaknai dengan pembelajaran online, namun dapat juga berupa aplikasi offline dengan berbagai strategi penyampaian materi dalam bentuk digital based content khususnya untuk pembelajaran yang daerahnya tidak dapat terjangkau dengan internet yang baik.

Sekolah banyak yang melakukan hal inovasi dalam proses bisnis yang berupa pembelajaran dimasa pandemi yaitu dengan cara online (online schooling) yang dapat digunakan yaitu platform digital. Peran kedua orangtua dalam menghadapi pendidikan di masa pandemi covid-19 pembelajaran sangat besar dalam proses pembelajaran yang dilakukan peserta didik di rumah (home-schooling). Ke depan, Jika sekolah fisik tidak lagi relevan, maka platform online learning/online course yang dilengkapi dengan licensed certification akan booming. Orang tua lebih memilih menyekolahkan anak di rumah karena orangtua dapat memantau langsung milestone anak. Tentu saja kebehasilan gagasan ini terletak adanya dukungan regulasi dari Pemerintah (Daheri, Juliana, Deriwanto, \& Amda, 2020). 
Kegiatan yang dapat dilakukan dalam sebuah peristiwa yang terjadi didunia saat ini menjadi awal terjadinya sebuah perubahan untuk inovasi yang cepat. Gagasan Survival Innovation di dunia pendidikan menjadi salah satu titik awal revolusi pendidikan Indonesia pada pasca pandemi Covid-19. Sudah jelas bahwa melalui pandemi ini, Dunia Pendidikan Indonesa dapat mengambil pelajaran penting, sehingga yang paling penting dan lebih mendesaknya penyebaran pengetahuan tanpa lintas batas, baik lintas usia, dan lintas semua bagian masyarakat.

Teknologi yang digunakan dalam pembelajaran online sangat berperan pada masa pandemi Covid-19, maka dari itu tugas yang dilakukan oleh semua pihak untuk terus menggali potensi dengan sepenuhnya. Pada Akhirnya semua yang dilakukan dalam pembelajaran dapat melalui gagasan Survival Innovation sehingga dapat diusulkan sebuah model pendidikan hybrid yang akan menjadi bagian integral dan tidak terpisahkan dalam sistem pendidikan yang ada di Indonesia, dimana pembelajaran offline tradisional dan e-learning dapat berjalan seiring setelah pandemi Covid-19 (Kusumastuti, 2014).

Siswa yang kurang antusias atau kurang serius dalam melakukan pembelajaran terlihat dalam gerakan-gerakan yang ditunjukan dalam bersikap mengikuti pembelajaran seni tari, hal semacam ini sesungguhnya amat menjengkelkan dan membosankan yang dihadapi oleh guru. Masalah yang seperti itu perlu dihadapi dengan penuh kesabaran dan ketenangan, sambil mengupayakan dan mencari berbagai solusi untuk mengatasi masalah dan hambatan yang ada. kesabaran yang antusias dirasakan oleh paraguru untuk menghadapi semua keadaan yang terjadi saat masa pandemi Covid-19.

\section{Kesimpulan}

Pembelajaran online yang terjadi saat ini pastinya akan kurang bermakna tanpa sinergitas strategi dan metode pembelajaran yang tepat. Salah satu penerapan yang dapat dilakukan untuk mempermudah pembelajaran online adalah pembelajaran yang berbasis proyek. Komponen yang paling utama dalam pembelajaran berbasis proyek adalah mengajukan pertanyaan atau masalah yang dihadapi. Untuk menghadapi semua dalam pembelajaran online dapat disajikan sesuatu untuk menyusun dan memulai aktivitas yang menekankan kepada sejumlah proyek sampai didapatkannya hasil akhir berupa produk sebagai rangkaian aktivitas komunikasi individu atau berbagai hasil tugas yang menjawab pertanyaan. Kesabaran yang dilalukan siswa dalam menghadapi masa pandemi Covid-19 memang harus membutuhkan kesabaran yang maksimal. Banyak sisiwa yang terdapat kurang antusias atau kurang serius dalam melakukan gerakan-gerakan, hal semacam ini sesungguhnya sangat menjengkelkan dan membosankan. Pada akhirnya masalah yang seperti itu perlu dihadapi penuh kesabaran dan ketenangan, sambil mengupayakan dan mencari berbagai macam solusi untuk mengatasi masalah dan hambatan yang ada. Namun demikian, efektivitas pembelajaran online bervariasi di antara kelompok umur. Pada dasarnya anak-anak yang lebih muda banyak memerlukan lingkungan yang terstruktur, karena anak-anak muda tersebut lebih mudah 
terganggu. Untuk mendapatkan manfaat penuh dari pembelajaran online, perlu ada upaya bersama untuk menyediakan struktur ini. Dengan mereplikasi kelas fisik melalui kemampuan video, menggunakan berbagai alat kolaborasi dan metode keterlibatan menggugah inklusi, personalisasi dan intelijen dari siswa.

\section{Ucapan Terima Kasih (Opsional)}

Terima kasih ditujukan kepada Dosen Evaluasi Pendidikan Seni Pasca Sarjana UNNES, Rombel Kelas Khusus.

\section{Daftar Pustaka}

Alaby, M. A. (2020). Media Sosial Whatsapp Sebagai Media Pembelajaran Jarak Jauh Mata Kuliah IImu Sosial Budaya Dasar (ISBD). Ganaya: Jurnal IImu Sosial Dan Humaniora, 3(2), 273-289.

Arifin, M. (2020). Manajemen pembelajaran pendidikan jarak jauh untuk millenial. In Kumpulan Penelitian dan Pengabdian Dosen.

Daheri, M., Juliana, Deriwanto, \& Amda, A. D. (2020). Efektifitas WhatsApp sebagai Media Belajar Daring. Jurnal Basicedu, 3(2), 524-532. https://doi.org/10.31004/basicedu.v4i4.445

Handayanto, R., Tripathi, N. K., Kim, S. M., \& Herlawati, H. (2018). Land Use Growth Simulation and Optimization for Achieving a Sustainable Urban Form. TELKOMNIKA (Telecommunication Computing Electronics and Control), 16(5), 2063-2072. https://doi.org/10.12928/telkomnika.v16i5.9309

Kusumastuti, E. (2014). Penerapan Model Pembelajaran Seni Tari Terpadu Pada Siswa Sekolah Dasar. Mimbar Sekolah Dasar, 1(1), 7-16. https://doi.org/10.17509/mimbarsd.v111.858

Moore, J. L., Dickson-Deane, C., \& Galyen, K. (2011). E-Learning, online learning, and distance learning environments: Are they the same? Internet and Higher Education, 14(2), 129135. https://doi.org/10.1016/j.iheduc.2010.10.001

Prajana, A., Ilmiah, P., Fauzi, A. A. R., Studi, P., Komunikasi, I., Komunikasi, F., .. Zuliarso, E. (2018). Pemanfaatan Aplikasi Whatsapp dalam Media Pembelajaran di UIN Ar-Raniry Banda Aceh. Cyberspace: Jurnal Pendidikan Teknologi Informasi, 2(2), 3.

Salim, A., Sangthong, B., Martin, M., Brown, C., Plurad, D., \& Demetriades, D. (2006). Whole body imaging in blunt multisystem trauma patients without obvious signs of injury: results of a prospective study. Archives of Surgery, 141(5), 468-475.

Selfiyani, D. (2011). Makna simbolis tari sindhung lengger dinas pariwisata dan kebudayaan kabupaten wonosobo skripsi.

Setiawan, A. R., Puspaningrum, M., \& Umam, K. (2019). Pembelajaran Fiqh Mu'Āmalāt Berorientasi Literasi Finansial. TARBAWY: Indonesian Journal of Islamic Education, 6(2), 187-192. https://doi.org/10.17509/t.v6i2.20887 
Susilo, A., \& Sofiarini, A. (2020). Pembelajaran Sejarah Online Mahasiswa STKIP PGRI Lubuklinggau Dimasa Pandemik Covid 19. Jurnal Pendidikan Sejarah Dan Riset Sosial Humaniora (KAGANGA), 3(1), 24-32.

Tannehill, D. B., Serapiglia, C. P., Guiler, J. K., \& Sharp, J. (2018). Information Systems Education Journal. 16(3).

Yuliandari, D., Handayanto, R. T., \& Herlawati, H. (2010). Structural Equation Modeling for Analyzing Factors That Influence Student and Women Lecturer Behavior in Using Facebook. International Seminar of Information Technology, 68-77. 